
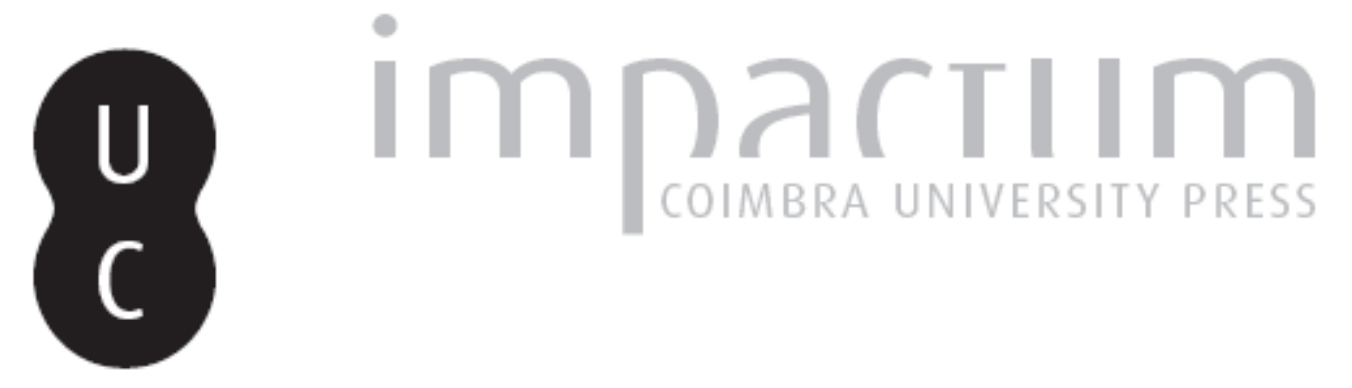

\title{
A Galiza e a cultura trovadoresca peninsular
}

Autor(es): $\quad$ Oliveira, António Resende

Publicado por: Imprensa da Universidade de Coimbra

URL persistente:

http://hdl.handle.net/10316.2/42908

DOI:

https://doi.org/10.14195/2183-8925_11_1

Accessed : $\quad$ 26-Apr-2023 12:30:56

A navegação consulta e descarregamento dos títulos inseridos nas Bibliotecas Digitais UC Digitalis, UC Pombalina e UC Impactum, pressupõem a aceitação plena e sem reservas dos Termos e Condições de Uso destas Bibliotecas Digitais, disponíveis em https://digitalis.uc.pt/pt-pt/termos.

Conforme exposto nos referidos Termos e Condições de Uso, o descarregamento de títulos de acesso restrito requer uma licença válida de autorização devendo o utilizador aceder ao(s) documento(s) a partir de um endereço de IP da instituição detentora da supramencionada licença.

Ao utilizador é apenas permitido o descarregamento para uso pessoal, pelo que o emprego do(s) título(s) descarregado(s) para outro fim, designadamente comercial, carece de autorização do respetivo autor ou editor da obra.

Na medida em que todas as obras da UC Digitalis se encontram protegidas pelo Código do Direito de Autor e Direitos Conexos e demais legislação aplicável, toda a cópia, parcial ou total, deste documento, nos casos em que é legalmente admitida, deverá conter ou fazer-se acompanhar por este aviso.

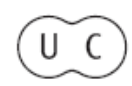


REVISTA DE HISTÓRIA DAS IDEIAS 11

\section{CULTURA POLÍTICA MENTALIDADES}

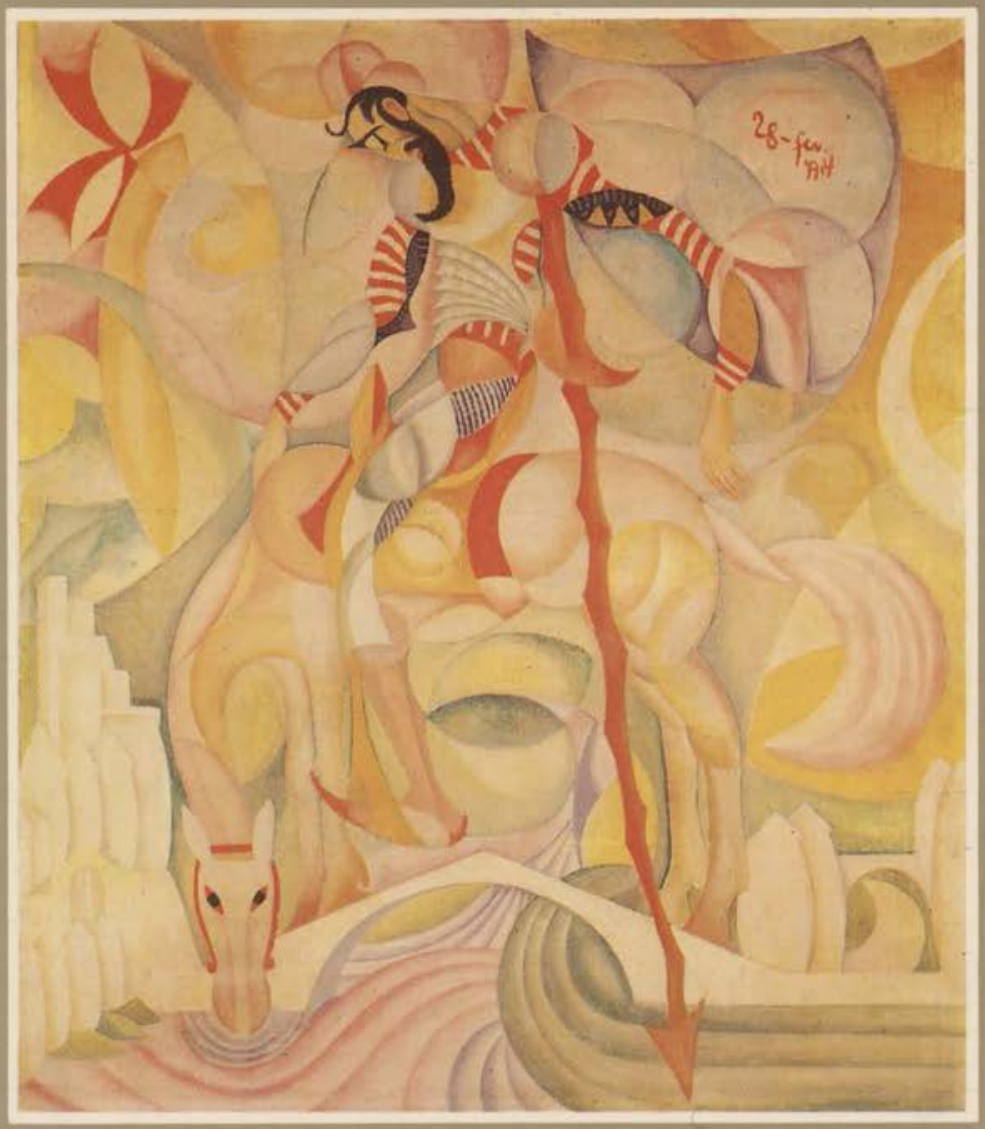

INSTITUTO DE HISTORIA E TEORIA DAS IDEIAS FACULDADE DE LETRAS 


\section{A GALIZA E A CULTURA TROVADORESCA PENINSULAR **}

A geografia da lírica galego-portuguesa, nos seus traços gerais, é bem conhecida ${ }^{1}{ }^{1}$. Com poucas excepções, esta manifestação cultural desenvolveu-se no ocidente peninsular dentro de uma vasta área dos reinos castelhano, português e leonês, sendo delimitada, no período de sua maior extensão, por centros urbanos como a Corunha, Burgos, Toledo, Sevilha e Lisboa.

Tal não significa, porém, que a adesão à canção trovadoresca tenha sido idêntica em toda a área agora circunscrita. $\mathrm{Na}$ verdade, tem sido justamente assinalado o reduzido peso numérico dos autores castelhanos $\left({ }^{2}\right)$, situação que encontra algum paralelismo em Portugal quando procuramos reunir o grupo de trovadores do centro e sul do território. Aqui. exceptuando o contributo da família régia, encontramos também poucos autores cuja naturalidade se situe ao sul do Douro: apenas João Soares de Paiva e Vasco Martins de Resende - pertencentes, no entanto, a uma região limítrofe do Minho-, Estevão da Guarda, Rodrig'Eanes d'Alvares Estevão Fernandes d'Elvas, Vidal, judeu de Elvas e, talvez, João Fernandes d'Ardeleiro $\left({ }^{3}\right)$. No entanto, tal como em Castela, o

* Faculdade de Letras da Universidade de Coimbra.

** Cont nuamos a beneficiar da atenção exigente do Professor Doutor José Mattoso. A redaccão final deste estudo contou igualmente com a frutuosa troca de opiniões estabelecida com o Dr. José Carlos Ribeiro Miranda, da Universidade do Porto, sobre o tema.

(1) C. Michaëlis de Vasconcelos, Cancioneiro da Ajuda, II, Halle, 1904, pp. 604-614.

(2) Cf. G. Tavani, Ensaios Portugueses, Lisboa, 1988, pp. 21-26.

(3) W. Pagani, Il canzoniere di Estevan da Guarda, sep. de Studi Mediolatini e Volgari, XIX, Pisa, 1971. pp. 57-59, optou, justifica- 
parco número de trovadores destas regiões foi contrabalançado pela presença nelas de autores de outras zonas, em particular junto das cortes régias portuguesa e castelhana. A importância destas - principalmente das de D. Afonso III e D. Dinis, em Portugal, e de D. Afonso X, em Castela - como centros aglutinadores de trovadores e jograis, tem sido salientada também pela crítica $\left({ }^{4}\right)$ e terá sido, sem dúvida, o seu contributo neste domínio o principal causador de uma tão ampla extensão geográfica da lírica cortesã. Não é por acaso que os centros urbanos referidos inicialmente constituiram, com excepção da Corunha, os principais centros das cortes régias portuguesa e castelhana $\left(^{5}\right)$.

Se, todavia, optássemos por uma geografia da naturalidade dos autores, e não já das cortes régias onde foram acolhidos, o mapa traçado inicialmente seria substancialmente reduzido. Basta pensarmos no grupo de trovadores e jograis galegos - constituindo, por si só, mais de um terço do conjunto dos autores dos cancioneiros $\left({ }^{8}\right)$ - e no grande número de trovadores portugueses naturais do Minho $\left({ }^{7}\right)$, para termos

damente quanto a nós, pela naturalidade portuguesa do autor. Sobre a sua cronologia e actividade na corte, pode ver-se, entretanto, A. Resende de Oliveira «Do Cancioneiro da Ajuda ao Livro das Cantigas do Conde D. Pedro. Análise do acrescento à seccão das cantigas de amigo de $\omega »$, Revista de História das Ideias, 10, 1988, p. 727 , onde se encontram igualmente fichas biográficas sobre Rodrig'Eanes d'Alvares e João Fernandes d'Ardeleiro. Note-se, no entanto, que alguns trovadores, apesar de originários de linhagens estabelecidas no Minho ou Trás-os-Montes, pelas ligações mantidas com a corte régia, acabaram por se estabelecer no centro e sul do território. Assim aconteceu com Fernão Fernandes Cogominho, João Peres de Aboim, João Soares Coelho, Rodrig'Eanes Redondo, etc. A progressão para sul destes e outros trovadores deve ser entendida num contexto mais geral que levou a um deslocamento de muitos nobres, em particular filhos segundos e bastardos, para a região da Beira, Estremadura e Alentejo, ou mesmo para fora de Portugal, à procura de meios de fortuna que lhes eram negados no norte pela implantação do sistema linhagístico. Cf. José Mattoso. A Nobreza Medieval Portuguesa. A família e o poder, Lisboa, 1981, pp. 287-311 e 353-369. pp. $255-267$.

(4) Cf. G. Tavani, A poesia lírica galego-portuguesa, Vigo, 1986,

${ }^{(5)}$ Do lado português teríamos apenas de acrescentar Santarém, cuja importância no âmbito desta manifestação cultural foi assinalada por Pedro de Azevedo, «O trovador Martim Soárez e seu filho João Martinz», Revista Lusitana, V, 1898, pp. 115-136.

$\left.{ }^{6}\right)$ A. Resende de Oliveira, "A cultura trovadoresca no ocidente peninsular: trovadores e jograis galegos», Biblos, LXIII, 1988.

${ }^{(7)}$ É um dos elementos que se podem retirar, desde logo, das pesquisas biográficas levadas a cabo por C. Michaëlis nos inícios do século. As pesquisas por nós efectuadas reforçam, neste aspecto, as 
uma ideia do novo quadro geográfico a definir. Assim, os autores de ambas as regiões parecem ter sido determinantes, não só para o modo como o legado provençal se aclimatou no ocidente peninsular, mas também - em virtude da sua presença nas cortes régias anteriormente citadas - para a divulgação a aceitação em zonas mais vastas, do mundo de valores presente nos textos preservados pelos cancioneiros.

Ao propormo-nos analisar apenas o contributo galego, operamos uma nova divisão na segunda unidade geográfica acabada de esboçar. Como justificar esta fractura. quando se tem insistido acima de tudo na comunidade cultural constituída por minhotos e galegos neste domínio $\left({ }^{8}\right)$ ? Digamos que duas razões, de ordem diversa, nos impeliram neste sentido. A primeira tem a ver com a evolução da nossa investigação no âmbito desta temática. Alertados pela provável existência, em B e V, de um cancioneiro galego, e esclarecida, de algum modo, a cronologia desses autores, tentamos em seguida precisar, com novos documentos, o número de autores galegos presentes nos cancioneiros $\left({ }^{\circ}\right)$. $O$ presente estudo é a conclusão lógica da investigação anterior. Reavaliado o peso numérico dos autores em causa e redefinida a sua cronologia, impunha-se um primeiro balanço global da sua actividade no contexto desta manifestação cultural. Quanto à segunda das razões invocadas, ela prende-se com a existência de vários indícios apontando para diferenças significativas no modo como a lírica cortesã se implantou na Galiza e em Portugal. A título de exemplo, paderemos começar por nos perguntarmos porque é que a vertente jogralesca é tão importante na Galiza quando, em Portugal, não foi ainda identificado, com dados biográficos seguros, nenhum jogral entre os seus autores. Nesta perspec-

indicações desta investigadora. Enquanto não apresentamos os resultados globais dessa pesquisa podem ver-se, entretanto, as fichas biográficas dos autores portugueses apresentadas em A. Resende de Oliveira, «Do Cancioneiro da Ajuda....», np. 720-751. Apesar de incidirem sobre trovadores da segunda metade do séc. XIII ou da primeira metade do século seguinte, tardiamente incluídos no arquétipo de B e V, cerca de dois terços são naturais do Minho ou provenientes de linhagens que aí possuíam os seus centros senhoriais.

(8) C. Michaëlis de Vasconcelos, ob. cit., pp. 607-608. Álvaro J. da Costa Pimpão, História da Literatura Portuguesa. Idade Média, Coimbra, 1959, pp. 113-114.

(9) A. Resende de Oliveira, "Do Cancioneiro da Ajuda....», pp. 709-714; Idem, "A cultura trovadoresca....». Com o intuito de não quebrarmos a sequência deste trabalho com sucessivas notas relativas à justificação da naturalidade e cronologia dos autores galegos que forem sendo citados, remetemos também o leitor para as fichas biográficas apensas a ambos os estudos. 
tiva esperamos contribuir para estabelecer com maior nitidez o percurso galego, aguardando que ele faça sobressair a especificidade da sua inserção no meio trovadoresco peninsular.

\section{A classificação dos autores}

Até à década de sessenta, quando qualquer investigador abordava o problema dos agentes desta manifestação cultural, sobressaíam sempre três nomes cuja função era dissecada em maior ou menor profundidade: o trovador, de origem nobre, visto como poeta e compositor; o segrel, também de extracção nobre mas de poucos recursos, obrigado a utilizar as suas aptidões poéticas e musicais como meio de subsistência; o jogral, finalmente, de origem não nobre e cuja função consistiria em cantar e tocar as composições dos trovadores $\left({ }^{10}\right)$. Este quadro apoiava-se em algumas composições dos cancioneiros, mas fundamentalmente, na célebre Declaratio de Afonso X à Súplica de Giraut Riquier sobre os jograis $\left({ }^{11}\right)$. No entanto, tal como foi delineado, ele é hoje inaceitável, não só no que diz respeito aos agentes ou categorias sócio-culturais, mas também às funções que são atribuídas a cada um deles.

Quanto ao primeiro ponto, o que está em causa é a categoria de segrel. Em 1966, Valeria Bertolucci Pizzorusso, após análise das tenções e cantigas de escárnio onde a palavra é mencionada e da Súplica de Giraut Riquier e resposta de Afonso $\left.\mathrm{X}{ }^{12}\right)$, anotava a contradição existente entre ambas as fontes. Segundo ela, enquanto as composições identificavam

(10) Cf. C. Michaëlis de Vasconcelos, ob. cit., pp. 632-660; Ramon Menéndez Pidal, Poesia juglaresca y juglares. Aspectos de la historia literaria y cultural de España, Madrid, 1975, pp. 14-34; José Joaquim Nunes, Cantigas d'Amigo dos Trovadores Galego-Portugueses, I, Lisboa, 1973 (1.' ed. 1928). pp. 90-100; M. Rodrigues Lapa, Das origens da poesia lírica em Portugal na Idade Média, Lisboa, 1929, cap. VII; José Filgueira Valverde, Lírica medieval gallega y portuguesa, in Guillermo Díaz-Plaja (dir.), Historia General de las Literaturas Hispánicas, I, Barcelona, 1949, pp. 588-591; Alvaro Júlio da Costa Pimpão, ob. cit., pp. 66-72. Algumas sínteses recentes continuam ainda a utilizar a mesma divisão tripartida. Cf. Pilar Vásquez Cuesta, "Literatura Gallega», in José Maria Díez Borque, Historia de las Literaturas Hispanicas no Castellanas, Madrid, 1980, p. 678.

(11) Ed. e trad. castelhana em Carlos Alvar, Textos Trovadorescos sobre España y Portugal, Barcelona, 1978, pp. 178-193.

(12) Valeria Bertolucci Pizzorusso, «La suplica di Giraut Riquier e la risposta di Alfonso X di Castiglia», Studi Mediolatini $e$ Volgari, vol. XIV, 1968. As composições são transcritas nas pp. 122-131. 
claramente o segrel com o jogral, a Declaratio de Afonso X, pelo contrário, parecia associá-lo ao trovador, ao dizer que estes eram apelidados de segreis em todas as cortes. No entanto, segundo a mesma investigadora, a contradição era apenas aparente, tendo resultado da "degradação semântica" do termo, provocada pela aceitação progressiva da dualidade trovador-jogral. Assim, e fazendo-se eco de uma hipótese avançada anteriormente por Menéndez Pidal $\left({ }^{13}\right)$, na Península segrel seria, inicialmente, o nome por que eram conhecidos os cantores da lírica profana, tendo passado - com a hierarquização sofrida pelo meio trovadoresco e a consequente adopção da designação provençal de trovador e a reutilização do termo jogral - a sinónimo de jogral da corte.

Voltemos, porém, à Declaratio e à identificaçãa que D. Afonso X estabelece, segundo Pizzorusso, entre segrel e trovador:

$$
\begin{aligned}
& \text { "....hom apela 'joglars' } \\
& \text { totz cels dels esturmens, } \\
& \text { et als contrafazens } \\
& \text { ditz hom 'remendadors', } \\
& \text { et ditz als trobadors } \\
& \text { 'segriers' per totas cortz..... ( } \left.{ }^{14}\right) \text {. }
\end{aligned}
$$

Assim isolada, a frase parece dar razão a Pizzorusso. No entanto, ela faz parte de uma sequência em que o rei se refere aos vários nomes pelos quais o jogral é conhecido no seu tempo, assinalando os trejeitadores, os jograis propriamente ditos. os arremedadores, os trovadores e, finalmente, o seu elemento mais vil, os cazurros. Neste contexto, se bem apreendemos o sentido do texto. "trovadores" não aparece aqui na sua função habitual de substantivo, mas como adjectivo, isto é, concretizando um tipo particular de jogral, o jogral que, além de executante, é também compositor, trovador. Se esta leitura é correcta, desaparece a contradição anotada por Pizzorusso e a palavra segrel adquire um sentido preciso na Declaratio: o de etiquetar o jogral que sabe compor canções. Neste sentido, podemos dizer que todos os jograis cuja obra foi preservada pelos cancioneiros são segreis, desa-

(13) R. Menéndez Pidal. ob. cit., p. 22.

(14) Carlos Alvar, ob. cit., p. 183 (versos 168-173). Sobre o grau de participação de Afonso $\mathrm{X}$ nesta obra, veja-se V. Bertolucci Pizzorusso, ob. cit., pp. 25-27. 
parecendo, por outro lado, a ambiguidade da figura do segrel tal como ela era delineada $\left({ }^{15}\right)$.

Finalmente, no que diz respeito à delimitação das funções entre trovadores e jograis, a Declaratio vem confirmar a incorrecção da assimilação do jogral a um simples executante. $\mathrm{O}$ ponto de partida da necessidade de classificação e hierarquização dos jograis presente no texto de Afonso X é claramente denunciado na Suplicatio de Riquier: o mundo jogralesco tinha albergado ultimamente, segundo a autor, elementos menos dignos e sem os conhecimentos necessários, que cantavam, trovavam e tocavam instrumentos, ameaçando a honorabilidade da classe $\left({ }^{16}\right)$. Impunha-se, consequentemente, actuar sobre a realidade jogralesca, organizá-la racionalmente através de uma terminologia adequada, de modo a que os jograis pudessem ser reconhecidos facilmente e premiados segundo os seus méritos. Ou seja - e a resposta de Afonso $\mathrm{X}$ reflecte isso mesmo - o que estava em causa não era tanto o mundo jogralesco tal como ele existia na realidade, mas a melhor maneira de ultrapassar a anarquia que, segundo Riquier, o atravessava. Assim, o rei castelhano, na sua resposta a Riquier, preocupa-se em tornar «legível» esta anarquia através de uma ordenação dos jograis em várias categorias, consoante a arte ou artes praticadas e os locais onde as exercitavam, que nos leva dos jograis "cazuros», "que mostram o seu saber vil e sem graça por ruas e praças». aos jograis "doctores de trobar", uma espécie de elite do meio segrelesco $\left({ }^{17}\right)$.

O equívoco estabelecido, isto é, a identificação do jogral com o instrumentista, resultou certamente do facto de Afonso $\mathrm{X}$ ter utilizado a palavra jogral apenas quando se referiu aos cantores e tocadores de instrumentos $\left({ }^{18}\right)$. Do contexto geral da Declaratio parece claro, no entanto, que a mesma

(15) Ver a bibliografia indicada na nota 10. Pela sua importância para a compreensão da lírica peninsular, este problema mereceria um tratamento mais exaustivo que nos encontramos impossibilitados de prosseguir dada a natureza parcelar deste estudo e os objectivos deste capítulo. Contamos aprofundá-lo quando analisarmos globalmente a evolução desta manifestação cultural no ocidente peninsular.

(16) Carlos Alvar, ob. cit., p. 150 (vs. 616-635).

(17) Idem, ibidem, pp. 182-189 (vs. 126-375).

$\left.{ }^{18}\right)$ «hom apela joglars totz cels dels esturmens», e, «E silh c'ap cortezia et homes secs e sort se habon captener entre las ricas gens, por tocar esturmens, o per novas comtar d'autri, o per cantar autrus vers e cansos, o per d'autres faitz bos e plazens per auzir, podon ben possezir aquel nom de joglar». Carlos Alvar, ob. cit., p. 183 (vs. 168-169) e pp. 184-185 (vs. 222-233). 
palavra está subjacente às restantes designações utilizadas para definir estes agentes culturais $\left({ }^{19}\right)$.

Esclarecida a questão terminológica podemos, enfim, dar o elenco dos autores galegos, agrupando-os alfabeticamente em duas listas, consoante a sua pertença ao grupo dos trovadores ou jograis $\left({ }^{20}\right)$.

\title{
I. Trovadores
}

\author{
1. Afons'Eanes do Coton \\ 2. Afonso Soares Sarraça \\ 3. Airas Carpancho \\ 4. Airas Peres Vuitoron \\ 5. Airas Soares \\ 6. Fernand'Esquio \\ 7. Fernão Padrom \\ 8. Fernão Pais de Tamalancos \\ 9. Fernão Velho \\ 10. João Lopes d'Ulhoa \\ 11. João Nunes Camanês \\ 12. João Romeu de Lugo \\ 13. Lopo Dias
}

(19) Para uma mais fácil compreensão do que dizemos, traduzimos a partir da tradução castelhana de C. Alvar, a parte final do texto onde Afonso $\mathrm{X}$ resume o seu sentido geral (vs. 318-375): «Todos os que eram chamados jograis em geral, ficam assim divididos e repartidos pelo nome, e ainda o podemos explicar uma vez mais, como dissemos. Os que exercitam o seu mester e, de uma maneira vil, se deslocam a toda a parte, tocando sem vergonha os seus instrumentos e fazendo outras coisas ou cantando pelas praças e pelos caminhos, vivem em desonra. E porque desejam e se contentam com pequenos ganhos e desconhecem juízo e discrição para que sejam úteis em qualquer tipo de saber, e pela sua vil conduta, sejam chamados bufões: se para nada são bons, não lhes faz falta bom nome. E todos os que utilizam habilmente uma coisa, ou sabem tocar instrumentos, ou cantar, ou fazer bem outras coisas e que, com boa aparência e cortesia estão, por sua vontade, junto dos bons e acompanham a corte, merecem ser chamados jograis, mas são distintos dos trovadores. Estes são os que sabem fazer com o coração, 'coblas y dansas doblas', atrevidos sirventeses, albas e 'partimens', e sabem trovar palavras e sons e não se ocupam de mais nada na corte, a não ser enviar ou dizer o seu saber aos mais dotados. Estes sejam chamados, com justiça, trovadores e sejam chamados doutores de trobar os mais dignos que, com saber e sentido, fazem versos e canções e outras composições boas, proveitosas e agradáveis, com belos 'ensenhamens'....»

${ }^{(20)}$ Limitámo-nos a ordenar, de acordo com a categoria a que pertencem, o conjunto de compositores identificados como galegos no nosso trabalho "A cultura trovadoresca....», já citado. 
14. Mem Rodrigues Tenoiro

15. Nun'Eanes Cerzeo

16. Nuno Fernandes de Mirapeixe

17. Nuno Rodrigues de Candarei

18. Pai Gomes Charinho

19. Pai Soares de Taveirós

20. Pedr'Eanes Solaz

21. Pero da Ponte

22. Pero Garcia d'Ambroa

23. Pero Pais Bazoco

24. Pero Velho de Taveirós

25. Pero Vyvyaez

26. Rui Pais de Ribela

27. Vasco Praga de Sandim

\section{Jograis}
28. Abril Peres
29. A. Gomes
30. Airas Pais
31. Bernal de Bonaval
32. Fernão do Lago
33. Galisteu Fernandes
34. Golparro
35. João Airas de Santiago
36. João Baveca
37. João de Cangas
38. João de Requeixo
39. João Servando
40. Juião Bolseiro
41. Lopo
42. Lourenço
43. Martim Campina
44. Martim Codax
45. Martim de Caldas
46. Martim de Ginzo
47. Martim Padrozelos
48. Mendinho
49. Nuno Porco
50. Nuno Treez
51. Pai Calvo
52. Pero d'Ambroa
53. Pero d'Armea
54. Pero de Berdia
55. Pero de Ver
56. Pero Meogo 
Completamos a lista dos autores galegos com o grupo de clérigos dessa região.

57. Airas Nunes
58. Osoir'Eanes
59. Pai de Cana
60. Rui Fernandes de Santiago

Concluindo, em termos globais teremos 4 clérigos, 27 trovadores e 29 jograis, embora, como acentuámos em estudo anterior, a naturalidade de 5 dos jograis tenha de ser confirmada $\left.{ }^{21}\right)$. Finalmente, não incluimos nestas contagens alguns autores para os quais não dispomos de quaisquer dados sobre a sua naturalidade $\left({ }^{22}\right)$.

Não sabemos se Giraut Riquier, ao falar na invasão do campo jogralesco por indivíduos menos aptos que cantavam, trovavam e tocavam instrumentos, se referia à realidade indesmentível que era a pujança da escola jogralesca galega da qual pademos testemunhar, neste momento, a importância numérica. Se sim, a crítica era nova unicamente pela dimensão global que Riquier lhe dava. Na prática, apenas ampliava aquela que Afonso $\mathrm{X}$, anos antes e num contexta diferente $\left({ }^{23}\right)$, dirigira a Pero da Ponte:

«vos non trobades come proençal mais come Bernaldo de Bonaval; por ende non é trobar natural» $\left({ }^{24}\right)$.

(21) Referimo-nos a Galisteu Fernandes, Juião Bolseiro, Lourenço, Nuno Porco e Pai Calvo. Cf. A. Resende de Oliveira, «Do Cancioneiro da Ajuda....», pp. 709-714.

(22) São eles: Airas Moniz d'Asme, Diego Moniz, Estevão Faião, Garcia Martins, João Velaz, Mem Pais e Nuno Fernandes Torneol. Cf. A. Resende de Oliveira, "A cultura trovadoresca....".

(23) Cf. Jean-Marie D'Heur, Troubadours d'Oc et troubadours galiciens-portugais. Recherches sur quelques échanges dans la littérature de l'Europe au Moyen Age, Paris, 1973, pp. 291-299.

(24) B 487 (ed. facs., p. 246); V 70 (ed. facs., p. 37). A crítica de Afonso $\mathrm{X}$ tem dado origem a interpretações diversas. Cf. Jean Marie D'Heur, Troubadours d'Oc...., pp. 291-299 e José Carlos Ribeiro Miranda, $O$ discurso poético de Bernal de Bonaval (sep. da Revista da Faculdade de Letras. Linguas e Literaturas, II série, vol. I), Porto, 1985, pp. 130-131. 
Mas se esta hipótese é correcta, isto é, se Riquier, ao redigir a sua diatribe contra a confusão reinante no meio jogralesco, pensava também nos jograis galegos que acabariam por ser incluídos nos cancioneiros medievais, então teremos de situar no terceiro quartel do séc. XIII, contra todas as expectativas, a expansão da vertente jogralesca da canção trovadoresca peninsular, e, com ela, a da "cantiga de amigo". Veremos se a evolução dos géneros poéticos poderá, ou não, confirmar esta expansão tardia do género. De qualquer modo a Suplicatio, redigida em 1274 , reflecte, sem margem para dúvidas, o alargamento e a diversificação do meio jogralesco propiciados pela introdução de alguns dos seus elementos no ambiente da cultura trovadoresca.

\section{O âmbito cronológico}

No sentido de circunscrever melhor as coordenadas cronológicas do contributo galego comecemos por alargar o questionário a toda a produção trovadoresca peninsular. Concentrando-nos nos cancioneiros e nos elementos mais seguros que deles podemos retirar, isto é, na cronologia dos textos e dos autores, reavaliemos os dados adquiridos.

Entre os textos mais antigos, o único que sabemos ter sido produzido antes de 1200 é o sirventês de João Soares de Paiva, Ora faz ost'o senhor de Navarra $\left({ }^{28}\right)$, datado, segundo López Aydillo, de $1196\left({ }^{26}\right)$. Por esta altura, dos restantes autores dos cancioneiros, apenas Garcia Mendes d'Eixo, Pero Rodrigues de Palmeira e Rodrigo Dias dos Cameiros, teriam atingido a idade adulta. Independentemente de as composições

(25) B 1330 (ed. facs., pp. 605-606); V 937 (ed. facs., p. 325).

(26) E. Lopez Aydillo, «Los cancioneros gallego-portugueses como fuentes históricas», Revue Hispanique, 57 (1923), pp. 315-321. Segundo C. Michaëlis, ob. cit., pp. 592-595, duas outras composições poderiam ter sido feitas antes de 1200: a célebre "cantiga de guarvaia" de Pai Soares de Taveirós, que colocou em 1189, e a cantiga de amigo Ay eu coitada, atribuída por ela a D. Sancho I e situada em 1199, ano em que este rei deu foral à Guarda. Costa Pimpão contestou já, com bons argumentos, a data proposta por C. Michaëlis para a composição de Pai Soares (Cf. Alvaro J. da Costa Pimpão, ob. cit., pp. 111-112; sobre a identificação deste autor e de seu irmão Pero Velho de Taveirós, vejam-se as fichas respectivas em A. Resende de Oliveira, «A cultura trovadoresca....»). Quanto às dúvidas levantadas pela atribuição da cantiga de amigo a D. Sancho I, veja-se S. Pellegrini, "Sancio I - Alfonso X?» in Studi su Trove e Trovatori della Prima Lirica Ispano. -Portoghese, Bari, 1959 (1.a ed., 1937), pp. 78-93. Aguarda-se, entretanto, sobre esta atribuição, o estudo prometido por Elsa Gonçalves. 
dos dois últimos se terem perdido, por lacuna de A, B e V, não temos quaisquer indicações para atribuir uma actividade poética tão precoce a qualquer destes trovadores.

Se nos orientarmos agora para as composições consideradas mais tardias e que marcariam. consequentemente, a fase final desta manifestação cultural, verificamos que, por volta de 1335-1340, altura em que João, jogral de Leão. terá composto $A$ sa vida seia muyta $\left({ }^{27}\right)$, as cortes de D. Afonso IV de Portugal e do Conde de Barcelos ainda mantinham algum atractivo para um compositor como este jogral leonês. Ainda posterior, de 1352, será a cantiga de maldizer de Estevão da Guarda contra o jogral e astrólogo Martim Vasques $\left({ }^{28}\right)$. Surgindo como última composição datável dos cancioneiros, a sua cronologia coaduna-se em absoluto com os dados biográficos conhecidos do trovador em causa, falecido cerca de 10 anos depois $\left({ }^{29}\right)$.

Do confronto entre ambos os momentos analisados sobressai a presença de apenas trovadores portugueses e castelhanos em qualquer deles. O significado desta presença não é, porém. o mesmo nos finais do séc. XII e por volta de meados do séc. XIV. Com efeito, se procurarmos os centros dinamizadores desta manifestação cultural nos dois períodos visados, os elementos disponíveis apontam para duas geografias diferentes. Para uma geografia castelhano-aragonesa no primeiro momento - o sirventês de João Soares é composto em Aragão ou na fronteira castelhana com esse reino e por outro lado, o senhorio de magnate castelhano Rodrigo Dias situa-se precisamente nesta região - - para uma geografia portuguesa no segundo momento.

Definida a cronologia global e, ao mesmo tempo, os parâmetros da pesquisa a efectuar $\left({ }^{30}\right)$, o que é que nos mostram os textos e os autores galegos neste capítulo? Iniciando a nossa

(27) B 1116 red. facs., p. 513); V 707 (ed. facs., p. 253). Sobre a datação, veja-se C. Michaëlis de Vasconcelos. ob. cit., p. 588 e, para uma posição contrária, G. Tavani, A poesia lírica...., pp. $38-39$ e 44-45.

(28) B 1323 (ed. facs., pp. 601-602); V 928 (ed. facs., p. 321). Sobre a datação Cf. M. Rodrigues Lapa. Cantigas d'Escarnho e de mal dizer dos cancioneiros medievais galego-portugueses, Vigo, 1970, p. 196.

(29) Síntese biográfica em A. Resende de Oliveira, "Do Cancioneiro da Ajuda....», p. 727.

( $\left.{ }^{30}\right)$ Não desconhecemos que o termo a quo da canção trovadoresca do ocidente peninsular tem sido tratado com maior circunspecção por motivo da sua associação ao problema das origens líricas desencadeado pelo aparecimento das cantigas de amigo (Cf. G. Tavani, A poesia lírica..., pp. 11-14). Abordaremos esta questão na parte final deste trabalho. 
análise pelos autores da primeira geração $\left({ }^{31}\right)$, começaremos por observar que estas indicações não são tão seguras quanto as que fizemos em relação aos trovadores portugueses, em virtude das limitações dos dados biográficos recolhidos sobre os autores situados na zona inicial de B, isto é, sobre Airas Moniz d'Asme, Diego Moniz, Pero Pais Bazoco, João Velaz, Airas Soares e Nuno Fernandes de Mirapeixe. Em termos gerais, no entanto, eles apontam para uma actividade poética exercida já no séc. XIII e, provavelmente, no seu segundo quartel. Para Abril Peres, Osoir'Eanes, Pero Garcia d'Ambroa e Fernão Pais de Tamalancos os pontos de apoio são mais seguros. situando-os claramente na primeira metade do séc. XIII $\left.{ }^{32}\right)$. Mais difícil, porém, será determinar os anos em que terão começado a compor. A cronologia de um terceiro grupo de autores cuja obra tem sido situada na fase inicial desta manifestação cultural, é-nos dada pelas suas ligações entre si e a trovadores mais conhecidos e, num ou noutro caso, pela cronologia das suas composições. Referimo-nos a Afons'Eanes do Coton. Airas Peres Vuitoron, Bernal de Bonaval, Pai Soares de Taveirós, Pero da Ponte e Pero Velho de Taveirós. Todos eles se terão encontrado, na década de quarenta do séc. XIII, nas cortes de D. Fernando III e do infante D. Afonso, seu filho, embora, nalguns casos, tenham começado a compor pelo menos na década anterior. Do conjunto dos autores mencionados. o que aparece mais cedo com indicação da actividade profissional é Abril Peres, que identificamos com o jogral D. Abril presente num documento de 1221, mas em Lisboa e, segundo tudo indica, fazendo parte do séquito dos Sousas. Finalmente, quanto aos autores do cancioneiro galego cuja cronologia não está ainda completamente esclarecida $\left({ }^{33}\right)$, não é crível, atendendo aos elementos

(31) Nas reflexões que se seguem apoiamo-nos nos conhecimentos já existentes sobre os trovadores mencionados e nos dados biográficos incluídos nas obras citadas na nota 9. Somente introduziremos novos dados biográficos nos casos em que persistam dúvidas, por nós já resolvidas, sobre a cronologia dos respectivos autores.

( $\left.{ }^{32}\right)$ Fernão Pais de Tamalancos é tenente de Búbal, na Galiza, entre 1216 e 1242. Cf. Emilio Duro Peña, «El monasterio de Santa Comba de Naves", Anuario de Estudios Medievales, 5 (1968), p. 137; José Garcia Oro, La Nobleza Gallega en la Baja Edad Media. Las casas nobles y sus relaciones estamentales, Santiago de Compostela, 1981, p. 395.

(33) São eles: Fernão do Lago, Galisteu Fernandes, Golparro, João de Cangas, Martim Campina, Martim de Caldas, Martim de Ginzo, Martim Padrozelos, Mendinho, Nuno Porco, Nuno Treez, Pai Calvo, Pero de Berdia, Pero de Ver e Pero Meogo. 
de vária ordem que permitem fixar nos segundo e terceiro quartéis do séc. XIII os restantes autores do mesmo cancioneiro, não é crível, dizíamos, que a sua actividade poética se tenha desenvolvido antes do período definido anteriormente.

Deixando os autores e passando aos textos, a situação anterior não se modifica. O mais antigo será, até ao momento, a cantiga de amigo de Bernal de Bonaval onde se refere à "sagraçon de Bonaval», verificada em $1230\left({ }^{34}\right)$. O segundo em antiguidade é o pranto de Pero da Ponte à morte de D. Beatriz de Suábia $\left({ }^{35}\right)$. mulher de D. Fernando III de Castela e mãe de D. Afonso X, ocorrida em 1235.

Se avançarmos para a última geração de trovadores e jograis galegos, veremos que ela se situa, talvez, nas últimas décadas do séc. XIII. Os únicos autores documentados depois de 1290 são o jogral Airas Pais e Pai Gomes Charinho, ambos na corte de D. Sancho IV de Castela. O último viria a falecer pouco depois, em 1295, enquanto o primeiro, embora activo nos inícios do século seguinte, abandonara já as cortes do ocidente peninsular. Activos no último quartel do século terão estado ainda, A. Gomes, Airas Nunes, Fernand'Esquio, João Airas de Santiago, João Lopes de Ulhoa. João Romeu de Lugo, Lopo Lias, Nun'Eanes Cerzeo e Pai de Cana $\left({ }^{38}\right)$. Infelizmente, as suas biografias não permitem ainda ver com grande precisão os limites temporais da obra que nos deixaram. Quanto aos jograis do cancioneiro galego, o período em que ele terá sido compilado não justifica um alargamento significativo do âmbito cronológico assinalado $\left({ }^{37}\right)$.

A maioria dos textos destes autores é difícil de datar. Entre os que se referem a circunstâncias e acontecimentos históricos datáveis, os três mais tardios serão anteriores a 1290 . Os dois primeiros $\left({ }^{38}\right)$ de Pai Gomes Charinho, devem ter sido

(34) B 1140 (ed. facs., p. 522); V 731 (ed. facs., p. 260). Cf. J. Filgueira Valverde, ob. cit., p. 592.

(35) B 985bis (ed. facs., p. 458); V 573 (ed. facs., pp. 209-210).

(36) Se é o "Pay da Cana» mencionado no testamento de D. Nuno Gonçalves de Bendaña, de 1348. Segundo este documento, teria feito, enquanto vivo, um empréstimo a D. Nuno, que este procurava saldar mandando entregar a seus filhos certa quantia de dinheiro (Colección Diplomática de Galicia Histórica, 1901, doc. LXXII). Quanto a João Lopes, esta hipótese cronológica será correcta apenas no caso de o podermos identificar com o João Lopes de "Ulhoo" que doa bens ao mosteiro de S. Vicente de Fora, em Lisboa, em 1286 (TT., S. Vicente, m. IV, doc. 13).

(37) A. Resende de Oliveira, "Do Cancioneiro da Ajuda....", p. 713. (ed. facs., p. 163). 
feitos na sequência da sua substituição no cargo de Almirante do Mar, em 1287. O terceiro, de Airas Nunes, foi associado ao desafio lançado a D. Sancho IV de Castela por Afonso de la Cerda, seu sobrinho, e pelo rei de Aragão D. Afonso III, em $1289\left({ }^{39}\right)$.

Concluindo, elementos internos dos cancioneiros e dados biográficos dos autores em causa conjugaram-se para nos dar uma cronologia do movimento galego que, grosso modo, o circunscreve ao período situado entre 1225 e 1300 . Apesar dos passos a dar nos domínios da datação das cantigas e do conhecimento de trovadores e jograis, pensamos que as balizas cronológicas delineadas não deverão ser substancialmente modificadas.

\section{As cortes}

Em termos gerais, e como tem sido frisado por mais do que uma vez $\left({ }^{40}\right)$, o conhecimento dos centros impulsionadores desta manifestação cultural continua dependente dos estudos de C. Michaëlis ( $\left.{ }^{41}\right)$. O que equivale a dizer que os grandes focos produtores continuam a ser as cortes régias, em particular as de D. Fernando III e D. Afonso X, em Castela, e as de D. Afonso III e D. Dinis, em Portugal $\left({ }^{42}\right)$. Jean-Marie D'Heur, analisando as composições dos trovadores galego-portugueses que utilizaram o ocitânico bem como as composições dos trovadores ocitânicos que utilizaram o galego-português, acentuava, por sua vez, a importância das cortes castelhana e leonesa como centros onde se teriam efectuado as frutuosas influências recíprocas entre ambas as escolas poéticas $\left({ }^{48}\right)$.

Os dados recolhidos não podem, porém, considerar-se definitivos. Este facto foi implicitamente reconhecido por Tavani quando, exasperado com a ausência de indicações biográficas seguras sobre muitos jograis e trovadores dos

(39) B 883 (ed. facs., pp. 404-405); V 466 (ed. facs., p. 175). Cf. G. Tavani, Ensaios...., pp. 287-288.

(40) Anna Ferrari, Elsa Gonçalves, Maria Ana Ramos, Geografia da lírica galego-portuguesa, sep. de Tradicion, actualidade e futuro do galego (Actas do colóquio de Tréveris, 13 a 15 de Novembro de 1980), Santiago de Compostela, 1982, p. 194; Luciana Stegagno Picchio, La métode philologique. I. La poesie, Paris, 1982, p. 140.

(41) C. Michaëlis, ob. cit., cap. VI e pp. 610-614. Acrescente-se, em particular sobre os jograis, R. Menéndez Pidal, ob. cit., pp. 102-140.

(42) A mais recente sistematização dos nossos conhecimentos neste domínio deve-se a G. Tavani, $A$ poesia lírica.... pp. 243-273.

(43) Jean-Marie D’Heur, ob. cit., pp. 283-289. 
cancioneiros, reconheceu que «a tarefa de distribuir numa perspectiva histórico-geográfica os 153 trovadores e jograis galego-portugueses autores de pelo menos um texto chegado até nós é das mais desesperantes e frustrantes da filologia românica» $\left({ }^{14}\right)$. A luz do que conseguimos apurar de novo sobre trovadores e jograis da Galiza e traçado os limites cronológicos do seu contributo, vejamos as cortes que os terão acolhido, tentando, por fim, detectar as variações observadas nesse contexto e suas consequências.

Se algumas cortes régias se têm destacado como pólos aglutinadores da produção poética e musical de trovadores e jograis, essa proeminência deve-se não só às indicações extraídas das composições destes - em particular das cantigas de escárnio - , mas também à sua eventual presença nas chancelarias ou outros documentos régios. Iniciando, portanto, esta resenha pelas zonas mais iluminadas do tema, a corte de D. Fernando III terá albergado, a partir da década de trinta do séc. XIII, autores como Abril Peres $\left({ }^{45}\right)$, Afons'Eanes do Coton, Bernal de Bonaval, Lopo e Pero da Ponte. Os contactos de D. Afonso X com o meio trovadoresco peninsular são, seguramente, anteriores à sua subida ao trono castelhano, em 1252. Entre os autores galegos, poderão tê-lo acompanhado antes desse ano Airas Peres Vuitoron, Juião Bolseiro, Mem Rodrigues Tenoiro, Pero da Ponte - que se manterá na corte na década seguinte - e, talvez, João Nunes Camanês e Nuno Rodrigues de Candarei $\left({ }^{46}\right)$.

A partir da década de sessenta, ou mesmo antes, encontramos na sua corte Fernão Velho, João Airas de Santiago, João Baveca, Lourenço, Pero d'Ambroa, Pero d'Armea, Rui Fernandes de Santiago, Rui Pais de Ribela e, talvez, A. Gomes. A documentação de D. Sancho IV ${ }^{47}$ ) revela que na sua corte a cultura trovadoresca manteve, apesar de tudo, alguma viva-

(44) G. Tavani, A poesia lírica..., p. 243.

(45) Se é, como pensamos, o jogral D. Abril documentado em 1221, poderia ter já frequentado a corte de D. Afonso IX de Leão (1188-1230). A tenção com Bernal de Bonaval deve, no entanto, ser posterior a 1230 .

(46) Lopo é satirizado por Martim Soares, um dos trovadores portugueses que terão acompanhado D. Sancho II e o infante D. Afonso, futuro D. Afonso X, a Castela, em 1247. Por outro lado, Pero da Ponte e, indirectamente, Afons'Eanes do Coton e Bernal de Bonaval, são satirizados por D. Afonso X. Significarão estas críticas menor consideração pelos compositores ligados a D. Fernando III, onde o pendor jogralesco parecia mais acentuado?

(47) Cf. Mercedes Gaibrois de Ballesteros, Sancho IV de Castilla, I, Madrid, 1922, cap. II. 
cidade. A vertente galega, todavia, não terá sido importante. Registe-se, no entanto, a presença nesta corte de Airas Nunes, Airas Pais e Pai Gomes Charinho, este vindo certamente do períado anterior.

Ao contrário da castelhana, a corte portuguesa não parece ter sido um centro particularmente atractivo para os autores galegos. Se Abril Peres, Airas Peres Vuitoron, João Lopes de Ulhoa, Lourenço e Vasco Praga de Sandim, por motivos vários, passaram ou acabaram por se estabelecer em Portugal, de nenhum deles temos conhecimento de ligações estreitas com a corte. $\mathrm{O}$ mesmo se diga em relação à corte aragonesa, na qual esteve apenas Airas Pais, nos inícios do séc. XIV, e pela qual poderá ter passado Pero da Ponte.

O relevo adquirido pelas cortes régias no desenvolvimento da canção trovadoresca não deve fazer-nos esquecer alguns centros senhoriais cuja importância ficou também impressa nas composições dos trovadores. 0 mais conhecido destes centros é, sem dúvida, a corte do magnate galego D. Rodrigo Gomes de Trastâmara. O papel por ela desempenhado foi já assinalado nos inícios deste século por Lopez Ferreiro $\left({ }^{48}\right)$, que nela situou autores como Pero d'Ambroa, Pero d'Armea, João Baveca, João de Guilhade, Nuno Fernandes de Mirapeixe, Pedr'Amigo de Sevilha Pero Velho e Pai Soares de Taveirós e a famosa soldadeira Maria Balteira ( $\left.{ }^{(99}\right)$. A corte dos Haro, em Castela, terá também atraído trovadores e jograis galegos ainda na primeira metade do séc. XIII. Um deles, Pero da Ponte - a avaliar pelos conselhos dados a Marinha Lopes, pela sua presença em Castela e pelo pranto à morte de $\mathrm{D}$. Lopo Dias de Haro -, conhecia-a muito bem. Rui Pais de Ribela, se uma das suas composições foi feita na Biscaia $\left({ }^{50}\right)$, poderá, igualmente, ter passado por lá $\left({ }^{51}\right)$. Outro chefe de linhagem cuja morte, em 1238, foi cantada por Pero da Ponte, foi D. Telo Afonso de Meneses ou Albuquerque. E provável que a sua corte tenha acolhido trovadores e jograis, embora nos faltem outros elementos comprovativos. A irmã de D. Telo, D. Mor Afonso, casou na Galiza com o já

(48) A. Lopez Ferreiro, Historia de La Santa A. M. Iglesia de Santiago de Compostela, t. V, Santiago de Compostela, 1902, p. 371.

(49) Pai Soares e Pero Velho de Taveirós estiveram seguramente aí. Menos certa, mas muito provável, é a presença, junto de D. Rodrigo, de Nuno Fernandes de Mirapeixe, de Pero Garcia de Ambroa e ainda de Pero d'Ambroa e de Pero d'Ármea.

(50) B 1435 (ed. facs., pp. 632-633); V 1045 (ed. facs., p. 367).

(51) Está, por outro lado, documentado o interesse de alguns membros desta linhagem pelos trovadores provençais. Cf. Carlos Alvar, La poesia trovadoresca en España y Portugal, Madrid, 1977, pp. 143-146. 
citado D. Rodrigo Gomes e foi em sua casa que ocorreu um episódio relatado numa tenção entre Pai Soares e Pero Velho de Taveirós $\left({ }^{52}\right)$. Na corte castelhana dos Cameiros está comprovada a presença de trovadores provençais. O facto de Rodrigo Dias dos Cameiros aparecer nos cancioneiros com três composições, hoje perdidas $\left({ }^{53}\right)$, poderá, no entanto, significar contactos prolongados com trovadores galego-portugueses. Finalmente, continua por descobrir a identidade de D. Constança, em cuja casa se encontrava a dama cantada por Airas Carpancho, e ainda a da infanta em cuja corte Lopo Lias vira, ainda moça, Elvira Padroa $\left({ }^{54}\right)$.

Estas são, como dissemos, as zonas mais iluminadas. A elas não terão tido acesso muitos trovadores e jograis, embora seja de admitir que, pelo menos em alguns casos, essa ausência seja uma mera miragem sustentada apenas pelo desconhecimento de documentos mais esclarecedores. Olhando para os cancioneiros, os autores galegos dos quais se desconhecem as cortes frequentadas distribuem-se maioritariamente por duas zonas relativamente concentradas: a parte inicial da secção das cantigas de amor de $\omega$ e o cancioneiro galego, situado no nível $\alpha$ da secção das cantigas de amigo $\left({ }^{55}\right)$. Por outras palavras, autores, respectivamente, da primeira e segunda metades do séc. XIII $\left({ }^{56}\right)$.

Se não é possível tirar conclusões definitivas acerca das cortes frequentadas pelos autores galegos e da possível evolução verificada a este nível entre cerca de 1225 e 1300 , os materiais rapidamente sumariados sugerem-nos algumas reflexões sobre as fases inicial e final do contributo galego, aquelas onde os nossos conhecimentos são seguramente menores.

Quanto à primeira, isto é, ao período inicial, os elementos aduzidos parecem apontar para algo descurado até aqui: o

(52) B 142 (ed. facs., p. 80).

(53) Elsa Gonçalves, La Tavola Colocciana Autori Portoghesi, Paris, 1976, p. 28 (n. 31) e fot. 2.

(54) Ver, no entanto, as indicações de M. Rodrigues Lapa, Miscelánea de Lingua e Literatura Portuguesa Medieval, Coimbra, 1982, pp. 280-281.

$\left({ }^{55}\right)$ No primeiro grupo incluímos Afonso Soares Saraça, Airas Soares, Fernão Pais de Tamalancos, Osoir'Eanes e Pero Pais Bazoco. De Airas Moniz d'Asme, Diego Moniz, D. Juano e João Velaz, presentes também na zona inicial dos cancioneiros, desconhecem-se quaisquer dados, inclusivamente os relativos à sua naturalidade. Quanto ao segundo grupo, veja-se a lista dos autores do cancioneiro galego em A. Resende de Oliveira, "Do Cancioneiro da Ajuda....", pp. 709-710.

${ }^{(56)}$ Os limites cronológicos do segundo grupo, o dos jograis galegos, são-nos dados por Bernal de Bonaval e por Airas Pais. 
papel que as grandes cortes senhoriais do norte e noroeste da Península poderão ter desempenhado no eclodir da canção trovadoresca galego-portuguesa e na sua evolução até perto de meados do séc. XIII. Não nos referimos apenas a cortes galegas, como a de D. Rodrigo Gomes de Trastâmara, mas também às cortes castelhanas das linhagens de Haro, Lara, Cameiros, Meneses e outras, algumas delas visitadas e elogiadas por trovadores e jograis provençais e referidas por trovadores galegos ou, pelo menos, deixando supor a presença destes nessas paragens. Abertas ao exterior e ligadas entre si por múltiplos casamentos seriam, sem dúvida, centros propícios ao contacto com a canção provençal e, eventualmente, às primeiras tentativas por parte de autores peninsulares de comporem em galego-português. As futuras investigações neste campo poderão ajudar a esclarecer a biografia de trovadores mais obscuros e obrigar a recuar um pouco a cronologia inicial do contributo galego.

Reportando-nos, finalmente, aos últimos representantes galegos desta manifestação cultural, poderá ter-se verificado nos fins do séc. XIII um processo inverso ao ocorrido nos anos trinta e quarenta do mesmo século, no qual a canção trovadoresca galego-portuguesa começa a aparecer claramente vinculada à corte castelhana. Na verdade, ao reduzido número de autores presentes na corte de D. Sancho IV, contrapõe-se a maior vivacidade de algumas regiões galegas, mormente a região de Lugo, com A. Gomes, Fernand'Esquio, João de Requeixo, João Romeu de Lugo e Lopo Lias, e o triângulo Vigo-Pontevedra-Tui, com Fernão do Lago, Golparro, João de Cangas, Martim Codax, Mendinho, Nuno Treez, Pedr'Eanes Solaz e, provavelmente, alguns mais. Mas, agora, as ligações a cortes senhoriais importantes não são tão visíveis quanto na primeira metade do século. Sinal da degradação do movimento, confinado a cortes com projecção meramente local e sem o ambiente de abertura cultural propiciado pelas cortes senhoriais e régias anteriores? Será talvez cedo de mais para o afirmarmos. Falta, sem dúvida, situar com maior rigor no tempo alguns jograis e, por outro lado, precisar a sua geografia.

\section{Os géneros poéticos e sua evolução}

A Arte de Trobar apensa a B distinguiria, na obra dos trovadores e jograis dos cancioneiros, três grandes géneros poéticos: cantigas de amor, cantigas de amiga e cantigas de 
escárnio e de maldizer $\left({ }^{57}\right)$. Esta distinção, feita por volta de meados do séc. XIV, não era nova. De facto, a organização de $\omega$, compilação do século anterior e ponto de partida de B e V, obedecera já a uma tripartição do material poético consonante com os géneros acima citados, dispondo-os igualmente pela mesma ordem. Por outras palavras, na segunda metade do séc. XIII já estaria perfeitamente estabelecida junto dos compiladores, e certamente no meio trovadoresco, a consciência da distinção entre os três géneros. Esta consciência poderia, porém, não ser um dado adquirido nos inícios desta manifestação cultural. Forjada, sem dúvida, pela prática trovadoresca, teria subjacente a si não somente a inicial e decisiva influência provençal, mas também todo o processo posterior de adaptações e deslocamentos desse legado cultural que culminariam na reconhecida especificidade do canto cortês do ocidente peninsular $\left({ }^{58}\right)$.

A terminologia utilizada pelos trovadores nos cancioneiros parece confirmar o que dissemos. Numa rápida sondagem às composições dos autores anteriores a meados do séc. XIII nota-se, desde logo, a incipiência da definição dos géneros. A palavra mais frequentemente empregue é, sem dúvida, a de cantar ou cantares, aplicada indistintamente às cantigas de amor, às cantigas de amigo e às cantigas de escárnio e de maldizer. A mesma palavra surge, mais raramente, na expressão cantar d'amor, expressão esta que, no entanto, se utilizaria também para designar as "cantigas de amigo» $\left({ }^{59}\right)$.

A distinção entre tipos de cantigas deve ter começado pela diferenciação entre a temática amorosa e a satírica. Airas Peres Vuitoron faz já, antes de meados do séc. XIII, a separação de ambas $\left({ }^{60}\right)$ e, pela mesma altura, Afons'Eanes

(57) O pequeno tratado encontra-se, hoje, incompleto. A parte conservada do título III, onde a definiçã́o dos géneros teria lugar, permite-nos, no entanto, ter vma ideia dos critérios seguidos. Cf. Jean-Marie D'Heur "L'Art de Trouver du Chansonnier Colocci-Brancuti. Édition et analyse», Arquivos do Centro Cultural Português, IX, 1975, p. 374. Para um enquadramento da obra e do avtor, vejam-se as pp. 380-387.

(58) Cf. G. Tavani, A poesía lírica..., pp. 14-22.

(59) É o que se pode concluir da tenção entre Afons'Eanes do Coton e Pero da Ponte (B 969, ed. facs., p. 450; V 556, ed. facs., p. 203). Este facto foi notado já por C. Michaëlis que concluiu ser "possível que a nomenclatura dos diversos géneros ainda não estivesse bem fixada em meados do séc. XIII». Cf. C. Michaëlis de Vasconcelos, ob. cit., pp. 453-454.

(60) «.....ca ben trobamos d'escarnh' e d'amor....» (B 1481, ed. facs., p. 656; V 1092, ed. facs., p. 386). 
do Coton e Pero da Ponte referem-se explicitamente às cantigas de escárnio e de maldizer $\left(^{61}\right)$. A definição de cada um dos grandes campos temáticos, o amoroso e o escarninho, ter-se-á verificado, ainda segundo as composições dos cancioneiros, ao longo do terceiro quartel do mesmo século. Reportando-nos aqui apenas à distinção, no primeiro desses campos, entre cantigas de amor e cantigas de amigo, a primeira composição onde aparecem claramente diferenciadas será, talvez, a tenção entre Lourenço e Rodrig'Eanes $\left.{ }^{(62}\right)$. Na sequência desta evolução a compilador de $\omega$ pôde, finalmente, organizar o cancioneiro a partir dos géneros já consagrados $\left({ }^{63}\right)$.

Poderemos depreender, da sondagem efectuada, uma certa progressão, por parte dos autores dos três primeiros quartéis do séc. XIII, no que diz respeito à consciencialização dos vários tipos de cantigas que compunham. Se atendermos aos autores citados - Afons'Eanes do Coton, Airas Peres Vuitoron, Lourenço e Pero da Ponte - , essa consciencialização parece ter-se verificado mais rapidamente nas cortes régias peninsulares, nomeadamente nas cortes de Fernando III e Afonso $\mathrm{X}$, ambas frequentadas por estes compositores. $\mathrm{O}$ que, em última análise, remeterá para uma prática mais precoce, nas referidas cortes, dos três géneros poéticos em vias de classificação e definição. $\mathrm{O}$ quadro da produção dos autores

(61) "Covilheyra velha, se vos fezesse grand'escarnho...." (B 1587, ed. facs., p. 706; V 1119, ed. facs., p. 395), «....A min foy feit'aquel cantar de mal dizer» (B 1650, ed. facs., p. 746; V 1184, ed. facs., p. 418). $\mathrm{Da}$ segunda composição, de Pero da Ponte, depreende-se que aquele "cantar de mal dizer" se identificava com a cantiga de escárnio tal como foi posteriormente definida pelo tratado de poética apenso a B. Consequentemente, se a separação das temáticas amorosa e satírica era perfeitamente perceptível para os autores de meados do séc. XIII, as suas composições revelam, por outro lado, pouca clareza na delimitação interna de cada uma dessas temáticas.

(62) «Rodrig'Eanes.... e a vos nunca vos vimos fazer cantar d'amor nem d'amigo....» (V 1032, ed. facs., pp. 360-361). O Rodrig'Eanes da tenção será um dos três trovadores portugueses com esse nome, todos activos na segunda metade do séc. XIII: Rodrig'Eanes d'Alvares, Rodrig'Eanes de Vasconcelos e Rodrig'Eanes Redondo.

(63) Algumas rubricas da secção das cantigas de escárnio e de maldizer de $\omega$ - como, por exemplo, «E Ffernam Velho fez esta cantiga d'escarnh'e de maldizer" -, pertencentes aos originais de que se serviu o compilador deste cancioneiro (ou por este redigidas?), revelam que não estava ainda estabelecida a distinção entre cantigas de escárnio e cantigas de maldizer. 
galegos cuja obra situamos por volta do segundo quartel do séc. XIII $\left({ }^{64}\right)$, poderá reforçar o que dissemos:

\begin{tabular}{|c|c|c|c|c|}
\hline Autores & C.A. & C.AM. & C. ESC. & Outras \\
\hline Afons'Eanes de Coton & 2 & $3(?)$ & 16 & \\
\hline Bernal de Bonaval & 10 & 8 & 1 & \\
\hline Fernão Pais de Tamalancos & 5 & & 3 & \\
\hline Lopo & 3 & 8 & & \\
\hline Nuno Fernandes de Mirapeixe & 2 & & & \\
\hline Osoir'Eanes & 8 & & & \\
\hline Pai Soares de Taveirós & 10 & $3(?)$ & 2 & \\
\hline Pero da Ponte & $7(?)$ & 7 & 34 & 6 \\
\hline Pero Garcia de Ambroa & 1 & & & \\
\hline Pero Velho de Taveirós & & & 1 & \\
\hline Vasco Prada de Sandim & 25 & 4 & & \\
\hline Totais & 73 & 33 & 57 & 6 \\
\hline N..$^{\circ}$ autores & 10 & 6 & 6 & 1 \\
\hline
\end{tabular}

Apesar do indiscutível predomínio das cantigas de amor, em número de composições e autores, fruto do impacto da influência provençal no meio trovadoresco peninsular, é notória já a atenção dedicada aos restantes géneros. Por outro

(64) Neste quadro, e no seguinte, incluímos apenas os autores cuja cronologia está estabelecida com algum rigor. Os dados numéricos dos três quadros apresentados incluem também as composições registadas no índice de Colocci, mas não preservadas pelos cancioneiros no seu estado actual (Cf. Elsa Gonçalves, ob. cit., pp. 21-22). Os valores globais a que chegamos não devem ser tomados como absolutos, em virtude da existência de algumas duplas atribuições ainda não resolvidas (Cf. G. Tavani, Repertorio Metrico della Lirica Galego-Portoghese, Roma, 1967, pp. 375-518; Jean-Marie D'Heur, «Nomenclature des troubadours galiciens-portugais (XIIe-XIVe siècles)», Arquivos do Centro Cultural Português, VII, 1973, pp. 21-27 e 43-100). 
lado, a quase totalidade dos autores mais produtivos estiveram ligados à corte castelhana, onde terão sido feitas a maior parte das cantigas de amigo e das cantigas de escárnio $\left({ }^{65}\right)$. No entanto, se ambos estes géneros poéticos estão já implantados neste ambiente, a sua aceitação por trovadores e jograis é algo diferente. Ao contrário do que sucede com as cantigas de escárnio, cerca de metade das cantigas de amigo devem-se aos jograis Bernal de Bonaval e Lopo, sinal, talvez, de uma introdução mais tardia nos paços régios e também da apetência do meio jogralesco pelo género. Razões que poderão explicar, finalmente, $\mathrm{o}$ atraso das referências à cantiga de amigo enquanto tal.

No contexto da prática dos três géneros poéticos em análise, o terceiro quartel do séc. XIII deve ter trazido algumas modificações ao panorama anterior. Perante a autonomia conquistada pelas cantigas de amigo em $\omega$, uma dessas modificações, talvez a mais importante, terá sido a definitiva afirmação deste género poético no meio trovadoresco. 0 quadro da obra dos autores galegos activos no último quartel do séc. XIII, que apresentamos de seguida, confirma esta evolução:

\begin{tabular}{|c|c|c|c|c|}
\hline Autores & C.A. & C.AM. & C.ESC. & Outras \\
\hline A. Gomes & & & 1 & \\
\hline Airas Nunes & 7 & 3 & 4 & 1 \\
\hline Airas Pais & 2 & 2 & & \\
\hline Fernand'Esquio & 2 & 4 & 3 & \\
\hline João Airas de Santiago & 21 & 48 & 13 & 1 \\
\hline João Romeu de Lugo & & & 1 & \\
\hline Lopo Lias & & & 20 & \\
\hline Pai de Cana & & 2 & & \\
\hline Pai Gomes Charinho & 20 & 6 & 2 & 1 \\
\hline totais & 52 & 65 & $\overline{44}$ & 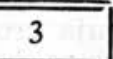 \\
\hline N..$^{\circ}$ de autores & 5 & 6 & 7 & 3 \\
\hline
\end{tabular}

${ }^{\left({ }^{65}\right)}$ Referimo-nos, nomeadamente, a Afons'Eanes do Coton, Pai Soares de Taveirós, Pero da Ponte, Bernal de Bonaval e Lopo, todos eles com estadias mais ou menos prolongadas nas cortes de D. Fernando III e de seu filho D. Afonso. 
O facto mais saliente é, sem dúvida, a posição de destaque das cantigas de amigo, embora ela se deva, sobretudo, ao elevado número de composições de João Airas de Santiago. Note-se, porém, que o peso numérico das suas cantigas de amigo poderá ser um bom sintoma da projecção do género nas cortes por ele frequentadas, uma das quais foi a de D. Afonso X. Além disso, não incluímos neste conjunto de autores nenhum dos jograis do cancioneiro galego cuja obra, constituída fundamentalmente por cantigas de amigo, se situará, grosso modo, na segunda metade do séc. XIII. Apesar de tudo, assistimos, de certo modo, a uma inversão das posições dos três géneros poéticos em relação ao quadro anterior. Se as cantigas de escárnio se quedaram numa posição subalterna, merece, apesar de tudo, a nossa atenção o facto de serem o género poético praticado pelo maior número de autores.

Resta-nos tecer algumas considerações sobre as opções detectadas na obra de trovadores e jograis galegos em relação aos tipos de composições aceites nos meios cortesãos. Como ponto de partida, atentemos no quadro com os números globais da participação de ambos nesta manifestação cultural:

\begin{tabular}{|c|c|c|c|c|c|}
\hline \multicolumn{2}{|c|}{ Categorias sócio-culturais } & C.A. & C.AM. & C.ESC. & Outras \\
\hline \multicolumn{2}{|c|}{ Trovadores (27) } & 155 & 57 & 115 & 7 \\
\hline \multicolumn{2}{|l|}{ Jograis (29) } & 68 & 198 & 55 & 1 \\
\hline \multicolumn{2}{|l|}{ Clérigos (4) } & 32 & 12 & 4 & 1 \\
\hline & totais & 255 & 267 & 174 & 9 \\
\hline
\end{tabular}

O dado mais elucidativo é, na verdade, o retirado da comparação entre a coluna das cantigas de amor e a das cantigas de amigo. Em termos gerais assiste-se a uma diferenciação clara entre trovadores e clérigos, por um lado, e jograis, por outro, na utilização de ambos os géneros poéticos, com os primeiros a optarem decididamente pela cantiga de amor e os segundos pela cantiga de amigo. No respeitante às cantigas de escárnio, jograis e clérigos mostram-se menos sensíveis ao género, levando, no contexto destas composições, a um reajustamento da divisão assinalada anteriormente. 


\section{Conclusão: a invasão da história}

0 acesso à produção poética medieval peninsular é-nos facultado graças à preservação, directa e indirecta, de vários cancioneiros compilados entre, aproximadamente, fins do séc. XIII e meados do séc. XIV $\left({ }^{68}\right)$. Atendenda ao âmbito cronológico desta manifestação cultural - iniciada nos finais do séc. XII e concluída por volta de meados do séc. XIV -, a fase de recolha e compilação das cantigas ocorreu, portanto, numa época tardia do movimento e numa altura em que ele tendia a circunscrever-se à corte régia portuguesa. Por outras palavras, a feitura dos cancioneiros verificou-se quando o ambiente trovadoresco estava perfeitamente estabilizado quanto aos seus agentes e tipa de composições e, por outro lado, organizado à volta das cortes régias portuguesa e castelhana. Neste contexto, os cancioneiros não podem deixar de reflectir esse momento da evolução da poesia lírica e, ao mesmo tempo, a própria visão deste movimento cultural por parte do círculo ou círculos cortesãos que incentivaram a recolha das composições.

A recepção da canção trovadoresca galego-portuguesa feita pela crítica contemporânea tem-se mostrado, no entanto, pouco sensível às dificuldades postas ao seu estudo em virtude de uma organização e transmissão tardias das composições. Isto é, não tem levado em linha de conta a operação de filtragem e depuração do movimento, montada pelo espírito ordenador e classificatório a que já fizemos referência ao tratar da terminologia relativa aos agentes desta expressão cultural e que está igualmente presente na compilação e organização dos cancioneiros. Se é certo que sem a existência de um Cancioneiro da Ajuda ou dos cancioneiros copiados em Itália no séc. XVI - cópias prováveis, embora com acrescentos, do "Livro das Cantigas", do conde D. Pedro - ou mesmo da Suplicatio de Giraut Riquier e da Declaratio de Afonso X, o nosso conhecimento da lírica peninsular seria muito limitada, não é menos verdade que a utilização destes documentos requer o seu prévio enquadramento histórico-cultural e ideológico, tendo em vista a definição do seu estatuto na compreensão do fenómeno em causa. Aliada às lacunas ainda existentes no domínio da cronologia de trovadores e jograis, a falta deste enquadramento terá sido, sem dúvida, determi-

${ }^{(8)}$ Cf. A. Resende de Oliveira, «Do Cancioneiro da Ajuda....», onde fazemos o ponto da situação sobre o problema da tradição manuscrita no período considerado e tentamos avançar com novos dados, retirados da análise parcial da secção das cantigas de amigo de B e V. 
nante para a visão estática que domina ainda os estudos sobre este tema. Uma visão onde se tem salientado apenas a importância das cortes régias no acolhimento deste movimento cultural, onde a diferenciação dos géneros poéticos e sua evolução não têm sido questionados em profundidade e onde apenas recentemente se pôs em causa a categoria do segrel como agente cultural, ao lado do trovador e do jogral $\left({ }^{67}\right)$.

Apesar do enquadramento histórico-cultural de algumas fontes não estar ainda definido, o simples facto de termos questionado a versão deste movimento cultural apresentada por aquelas que utilizamos permitiu-nos avançar com novos resultados em alguns domínios, nomeadamente os respeitantes à definição dos seus agentes culturais, das cortes onde foram acolhidos e também dos géneros poéticos aí incentivados. Resultados que, em termos globais, fizeram sobressair, assim o pensamos, a importância da intromissão da diacronia no estudo da lírica medieval peninsular. Mas, se nos vários vectores abordados nos foi possível perspectivar uma determinada evolução, isso foi conseguido também em virtude dos esclarecimentos introduzidos nas biografias dos autores, mormente na sua cronologia e condição social.

Concretizando, comparemos os dados obtidos sobre o contributo galego com os elementos já conhecidos para o conjunto desta manifestação cultural, restringindo-nos, para já, às suas vertentes numérica, sociológica e cronológica.

A importância da Galiza pode aferir-se desde logo, pelo elevado número de autores desta região presentes nos cancioneiros. Cerca de 60 num total de pouco mais de $160\left({ }^{68}\right)$, o que corresponde a mais de um terço desses autores, com

( ${ }^{(7)}$ É, como se terá notado, a ausência do historiador que está em causa. No campo filológico, os estudos desenvolvidos nas últimas duas décadas - dos quais nos permitimos destacar os de Anna Ferrari, Elsa Gonçalves, Giulia Lanciani, Giuseppe Tavani, Jean-Marie D'Heur e Luciana Stegagno Picchio -, saldaram-se por um conhecimento mais profundo dos textos e cancioneiros, infelizmente não acompanhado por igual interesse da parte da historiografia em relação aos autores e ao meio social e cultural em que se moviam. Apenas recentemente se notaram alguns sinais de mudança. Cf. José Mattoso, "Investigação histórica e interpretação literária de textos medievais", Ler História, 11, 1987, pp. 5-13.

(e8) As listagens mais recentes e completas, de G. Tavani, La poesía lírica...., pp. 277-329, e de Jean-Marie D'Heur, «Nomenclature....", pp. 21-27, ficam um pouco aquém deste número. Não é este o momento oportuno para darmos conta das razões que nos permitiram acrescentar alguns novos autores aos já conhecidos. Esperamos fazê-lo em breve no estudo que preparamos sobre as origens e evolução deste movimento cultural em Portugal. 
a possibilidade de a percentagem subir ainda um pouco caso algum dos de naturalidade desconhecida venha a ser considerado galego. Sendo do conhecimento geral o reduzido número de trovadores castelhanos, aragoneses ou mesmo provençais e italianos que compuseram em galego-português, é provável que o peso numérico dos autores galegos seja idêntico ao dos trovadores portugueses, constituindo-se assim ambos os grupos como os principais dinamizadores desta manifestação cultural na península. Algo que já era pressentido, mas que pode agora ser avaliado com maior precisão $\left({ }^{69}\right)$.

A pertinência da aproximação entre autores galegos e portugueses perde-se quando, ultrapassada a barreira dos números, procuramos inquirir sobre as categorias sócio-profissionais que se escondem por trás dessa provável paridade numérica. Aqui, a diferença é substancial e significativa. $\mathrm{Na}$ verdade, enquanto que em Portugal a canção trovadoresca parece ter sensibilizado apenas a nobreza $\left({ }^{70}\right)$, nos seus vários estratos, na Galiza, tendo-se estendido sobretudo por uma nobreza de segundo plano, seduziu também elementos não nobres. Referimo-nos naturalmente aos 29 jograis galegos presentes nos cancioneiros, cuja obra foi determinante na acentuação das diferenças entre o canto peninsular e o provençal. Se esta divergência nos agentes e nas soluções encontradas pelas líricas galega e portuguesa justificaria, por si só, a opção que tomamos ao isolar o contributo galego, não menos significativa nos parece, nesta perspectiva, uma segunda divergência: a cronológica. A análise feita aos limites cronológicos do contributo galego realçou, pela sua comparação com as primeiras e últimas composições conhecidas, a existência de duas cronologias distintas uma portuguesa e outra galega, na lírica peninsular. A portuguesa, abarcando todo o tempo desta manifestação cultural, isto é, iniciando-se nos finais do

(69) Se a importância do contributo galego nunca esteve em causa, o número de autores da Galiza presentes nos cancioneiros era considerado inferior ao dos portugueses. Cf. A. Resende de Oliveira, «A cultura trovadoresca....».

(70) Mantém-se em aberto a possibilidade de atribuição de uma naturalidade portuguesa a alguns dos jograis presentes nos cancioneiros, mormente a Diego Pezelho e Lourenço, cuja presença em Portugal é segura. Esta estadia e, em relação a Lourenço, os contactos estabelecidos com o meio trovadoresco português - dado o nomadismo dos agentes desta expressão cultural, em particular dos jograis - não devem, porém, ser sobrevalorizados neste contexto. De qualquer modo, a existência de jograis portugueses, caso se confirme, não terá qualquer significado quando confrontada com a vivacidade do mesmo meio na Galiza. 
séc. XII e prolongando-se até meados do séc. XIV; a galega, situando-se apenas entre, aproximadamente, 1225 e 1300 .

Como justificar a dualidade observada no campo cronológico, e também no dos autores, entre a Galiza e Portugal? Estaremos somente perante os imponderáveis da tradição manuscrita ou resultará ela da especificidade da aclimatação da lírica cortês na Galiza, com o consequente atraso na ligação a este movimento cultural e também com um esgotamento mais precoce do ideário a ele adscrito?

Embora seja prematura qualquer conclusão definitiva, a análise das cortes frequentadas pelos autores galegos e os géneros poéticos por eles praticados parecem apontar, com alguma nitidez, para a segunda hipótese acabada de formular. Com efeito, uma das condições de sobrevivência do canto cortês foi, não restam dúvidas, o apoio que obteve nas cortes dos magnates e reis do ocidente peninsular. Ora, no caso galego, esse apoio, dado inicialmente pelas cortes dos ricos-homens castelhanos e por uma ou outra corte galega, rapidamente foi circunscrito à corte régia castelhana, onde vamos encontrar um número significativo de autores galegos nor volta de meados e ainda no terceiro quartel do séc. XIII. Esta mutação, justificada pelo papel central ocupado pela corte castelhana após a junção dos reinos de Leão e Castela e numa altura em que esta centralizava o dinamismo da reconquista, tinha o seu contraponto na perda de importância social e política da alta nobreza galega no contexto do novo reino castelhano-leonês $\left({ }^{71}\right)$. Por outro lado, ao contrário do que sucedeu em Portugal, os círculos régios castelhanos. a partir dos inícios do reinado de D. Sancho IV, não deram continuidade a esse apoio. Os autores galegos viram-se assim confiados à sua região natal, sem encontrarem nela um ambiente cortesão propício ao desenvolvimento da sua actividade nos moldes em que evoluíra até então.

Estas transformações dos meios cortesãos, retiradas da análise às cortes frequentadas por trovadores e jograis galegos, não podem ter deixado de influenciar o espectro temático da canção cortês peninsular plasmado nos três géneros poéticos mais cultivados por esses autores. Embora as ligações a estabelecer entre cronologia. cortes e géneros pośticos necessitem ainda de alguns esclarecimentos sobre autores menos conhecidos, é possível, desde já, fazer uma primeira aborda-

(71) Salvador de Moxó, «La nobleza castellano-leonesa en la Edad Media. Problemática que suscita su estudio en el marco de una historia social», Hispania, XXX, n. ${ }^{\circ} 114,1970$, pp. 30-31. 
gem da evolução dos géneros neste contexto. Os elementos recolhidos revelam que, até cerca de 1240 - período em que a lírica peninsular se terá desenvolvido junto de algumas cortes senhoriais - , a cantiga de amor prevaleceu sobre os outros géneros poéticos nos círculos aristocráticos que incentivaram esta manifestação cultural $\left({ }^{72}\right)$. Os contactos dessas cortes com o ambiente cultural da Provença, nomeadamente através do acolhimento feito a trovadores e jograis dessa região, e, por outro lado, a função que a própria cantiga de amor aí terá desempenhado inicialmente junto da pequena nobreza que vivia na dependência do senhor $\left({ }^{73}\right)$, justificarão, assim o pensamos, esse ascendente.

A partir de 1240 e até à década de setenta do mesmo século, embora na obra dos autores galegos situados seguramente neste período a cantiga de amor continue a merecer alguma atenção, o facto mais saliente, por comparação com o período anterior, será a projecção alcançada pelas composições satíricas $\left({ }^{74}\right)$. Esta mutação acompanha a centralização do movimento na corte de $\mathrm{D}$. Afonso $\mathrm{X}$, onde o elevado número de trovadores e jograis, entre os quais alguns portugueses $\left({ }^{75}\right)$, e a própria actividade militar e política do rei criaram o ambiente propício à expansão do género.

A obra de alguns jograis presentes nesta corte, como João Baveca e Juião Bolseiro, mostra que o gosto pela cantiga de amigo se poderá ter desenvolvido também nesta altura. 0 certo é que, nas décadas finais do mesmo século, período no qual situamos as últimas composições galegas, a cantiga de amigo rivalizava já com os restantes géneros poéticos da

(72) Ver o quadro da obra dos autores galegos do segundo quartel do séc. XIIÎ.

${ }^{(73)}$ Explorámos o tema em «A mulher e as origens da cultura trovadoresca no ocidente peninsular", in A Mulher na Sociedade Portuguesa (Actas do Colóquio, Coimbra, 20 a 22 Março 1985), vol. II, Coimbra, 1986, pp. 21-34.

( ${ }^{74}$ Os autores em causa são Airas Peres Vuitoron, Fernão Velho, João Baveca, Juião Bolseiro, Lourenço, Mem Rodrigues Tenoiro, Pero da Ponte, Pero d'Ambroa, Pero d'Armea, Rui Fernandes de Santiago e Rui Pais de Ribela. Deixaram-nos, aproximadamente, 77 cantigas de amor, 59 cantigas de amigo, e 94 cantigas de escárnio e de maldizer. $O$ peso numérico do sector satírico deve ser um pouco atenuado em virtude da inclusão neste grupo de Pero da Ponte, trovador, que, embora presente na corte de $D$. Afonso $X$, vem já do período anterior.

${ }_{(75)}$ A. Resende de Oliveira, "Trovadores portugueses na corte de Afonso X», in Actas das II Jornadas Luso-Espanholas de História Medieval (no prelo). 
lírica peninsular $\left({ }^{78}\right)$. Se, como observámos, Giraut Riquier na sua Suplicatio se referia aos jograis galegos cuja obra é constituída essencialmente por cantigas de amigo, a importância do género neste período sairia ainda mais reforçada.

Apesar de tudo, não há indicações de que a corte régia tenha contribuído de uma maneira notória para a divulgação deste tipo de composições. Como vimos, a corte de D. Sancho IV regista um acentuado declínio da presença galega e as composições destes autores parecem indicar um refluxo do movimento para os seus locais de origem. Talvez este refluxo e a ausência dos ambientes cortesãos percorridos por trovadores e jograis até ao terceiro quartel do séc. XIII possam explicar a expansão de um género que, nas suas formas mais arcaizantes, tem sido associado ao meio popular ou a um ambiente pré-cortês e não ao meio aristocrático $\left({ }^{77}\right)$. Por outras palavras, esta feição popular do género poderá não ser mais do que um sintoma final do esgotamento de uma manifestação obrigada a procurar com mais afinco numa expressão cultural local o substituto de uma dimensão cortês e europeia em vias de extinção. Hipótese que a análise interna das cantigas de amigo, apoiada numa cronologia mais segura dos seus autores e num melhor conhecimento do meio ou meios que a impuseram, poderá esclarecer definitivamente.

A economia deste ensaio, ao prescindir da análise interna das composições e ao apoiar-se apenas nos autores galegos, não nos permite aprofundar esta questão nem, tão pouco, uma outra, com ela de qualquer modo relacionada: a do problema das origens da cantiga de amigo, dada a sua relevância no contexto peninsular. Não podemos porém, terminar sem nos interrogarmos sobre as consequências que a anterioridade da cantiga de amor em relação à cantiga de amigo - pressentida, quer na análise do âmbito cronológico do contributo galego $\left({ }^{78}\right)$, quer na análise da evolução dos géneros poéticos - , poderá trazer para uma reavaliação da questão.

(78) Ver o quadro da obra de autores galegos activos no últ mo quartel do século XIII. Relembramos a não inclusão neste quadro, por falta de dados cronológicos precisos, da quase totalidade dos jograis do cancioneiro galego.

( $\left.{ }^{77}\right)$ Uma rápida síntese do problema em Elsa Gonçalves, Maria Ana Ramos, A Lírica Galego-Portuguesa, Lisboa, 1983, pp. 29-32 e G. Tavani, A poesía lírica..., pp. 136-139, e bibliografia indicada na p. 137. Sobre a lírica peninsular e europeia anterior ao aparecimento dos trovadores, pode ver-se Margit Frenk, "La lírica pretrovadoresca», Grundriss der Romanischen Literaturen der Mittelalters, vol. II. Les Genres Lyriques, t. 1, fasc. 2, He.delberg, 1979, pp. 25-79.

${ }^{(78)}$ Acrescente-se a indicação do índice de Colocci, segundo a 
Com efeito, se a cantiga de amigo, perante os dados disponíveis, é mais tardia do que a cantiga de amor e se, por outro lado, foi já realçada a «homogeneidade formal» do conjunto da lírica peninsular $\left({ }^{79}\right)$, será legítimo equacionar o problema das suas origens fora do contexto em que ela, tal como a conhecemos, se inseriu, isto é, fora de uma manifestação cultural a cujas regras, salvaguardadas as diferenças entre os vários géneros, se submeteu? Não será ela um dos resultados, sem dúvida a mais importante, do processo de adequação do lirismo cortês de matriz provençal ao solo peninsular? Não estão em causa, naturalmente, as possíveis influências de localismos poéticos anteriores à implantação da canção cortês. O resultado final, no entanto, por via desta implantação, estaria longe dos hipotéticos modelos locais, como parece ressaltar da oposição estabelecida por Martim Soares entre os "desiguados" cantares de amor de um cavaleiro, louvados pelos aldeões e pelos concelhos, e os "fremosos e rimados" cantares dos trovadores $\left({ }^{80}\right)$. Por outras palavras, se a crítica de Martim Soares é certeira, as influências autóctones detectadas na cantiga de amigo tiveram de se moldar à forma provençal ou, se se preferir, ao modo como ela foi assimilada pelos trovadores galego-portugueses. Mas, neste caso, isso somente poderia ter-se verificado após a divulgação da canção provençal nas cortes do norte peninsular.

qual três dos trovadores mais antigos - João Soares de Paiva, Pero Rodrigues de Palmeira e Rodrigo Dias dos Cameiros -, teriam composto, se exceptuarmos o sirventês de João Soares de Paiva, apenas cantigas de amor (Cf. Elsa Gonçalves, ob. cit., p. 28, n. $.^{\circ} 23,29$ e 31 ). Quanto às cantigas de amigo é, como vimos, de 1230 aquela que conseguimos datar como mais antiga.

(79) G. Tavani, A poesía lírica...., pp. 83-96.

(80) B 1357 (ed. facs., pp. 615-616); V 965 (ed. facs., p. 334). 